\title{
Exploration of Properties of Concrete by Partial Replacement of Fine Aggregate with Clastic Sediment Stone Powder
}

\author{
Er. Farooq Ahmad Parray \\ Research Scholar, \\ Dept. of Civil Engineering. \\ Indo-Global Group of Colleges. Abhipur, Mohali, India
}

\author{
Er. Hema Rani , Er. Manjit Kaur \\ Assistant Professor, \\ Dept.of Civil Engineering \\ Indo-Global Group of Colleges Abhipur, Mohali. India
}

\begin{abstract}
Concrete is widely used composite material in civil engineering world. The components of concrete are cement, fine aggregate, coarse aggregate and water. River sand is most commonly used as fine aggregate. The river deposits are the most common source of fine aggregate. Now-a-days the natural river sand has become scarce and very costly due to greater demand than its supply. Going for an alternative or supplementary material which can be used as partial or full replacement of conventional material can play an important role in conservation of natural resources. Clastic sediment Stone powder disposal became a worldwide problem. This study has been carried out at $0 \%, 15 \%, 30 \%, 45 \%$ and $60 \%$ replacement of natural river sand. From experimental results it is observed that workability of concrete decreases with increase in clastic stone powder content. This decrement in workability may be attributed to finer size of clastic sediment stone powder particles than those of river sand particles.
\end{abstract}

Key Words: Clastic sediment stone powder

\section{INTRODUCTION}

Concrete is widely used composite material in construction world. Some alternative materials have already been used as a fine aggregate in concrete e,g. fly ash, steel slag, glass powder, marble powder etc. Clastic sediment Stone powder is considered a waste product obtained by breaking down larger size stones into smaller sizes for making coarse Aggregate. In India clastic stone powder is produced in large quantity and therefore their consumption becomes necessary in order to reduce environmental problems. By utilizing clastic stone powder as replacement of sand would reduce the environmental problems and also results in economical concrete construction.

Key words: workability, compressive strength, tensile strength, flexural strength.

\section{LITERATUR REVIEW}

V. L. Bonavetti et al (1994) studied the effect of stone dust on different properties of mortar. It was observed that the water required for maintaining a constant flow increases with increase in stone dust content in mortar. The air content of fresh mortar decreases until $10 \%$ of sand replacement by stone dust beyond that it increases to the same level as that of control mortar. The replacement was made in steps of $5 \%, 10 \%, 15 \%$, and $20 \%$. At the curing age of 7 days, the compressive strength increased by about $44 \%-72 \%$ than control mortar. However, at higher curing ages the compressive strength was same as that of control mortar. The flexural strength was improved at all ages of curing. The drying shrinkage was increased with increase in stone dust content and attributed this increment to increased water content of mortars containing stone dust. Sudharshan N. Raman et al (2005) assessed the compressive strength of concrete by replacing sand with quarry dust partially along with some admixtures viz. silica fume and class $-\mathrm{F}$ fly ash. It was observed that partial incorporation of quarry dust resulted in reduction of compressive strength and was more evident when quarry dust content increased. It was observed that compressive strength reduction was compensated by incorporation of silica fume and fly ash. Omar M. Omar et al (2012) investigated the influence of limestone waste as partial replacement for sand in concrete. The replacement was made in steps of $25 \%, 50 \%$ and $75 \%$. The compressive strength was checked at the curing ages of 7, 28 and 90 days. Marble powder was used as an additive in steps of $5 \%, 10 \%$ and $15 \%$ by weight of cement. The tests were done in two phases with varying cement content $(350$ $\mathrm{kg} / \mathrm{m}^{3}$ and $450 \mathrm{~kg} / \mathrm{m}^{3}$ ). It was found that, at $50 \%$ replacement increment in compressive strength was $12 \%$ than normal concrete at the curing age of 28 days. Increment in tensile strength and flexural strength were about $17 \%$ and $8 \%$ by using $50 \%$ lime stone waste and $15 \%$ marble powder. Husam Najm et al (2016) investigated the various properties of concrete by replacing sand with granite powder and iron powder. The replacement was made in steps of 5\%,10\%, $15 \%$ and $20 \%$. The compressive strength was best at $10 \%$ replacement of sand by granite powder, whereas splitting tensile strength and flexural strength were best at $15 \%$ and $10 \%$ respectively. Concrete containing iron powder has showed increment in compressive strength, splitting tensile strength and flexural strength with increase in iron powder content; however this increment was more evident in flexural strength than those of compressive strength and flexural strength. Aditya Rana et al (2016) determined the effect of different kinds of stone waste (lime stone, granite stone, marble etc.) on the properties of concrete and observed that these different kinds of stone wastes can be used in concrete partially, as their partial incorporation in concrete showed increment in strengths, greater resistance to acid attacks, very high resistance to chloride penetration and very low porosity as compared to the normal concrete. 
Prarthita Basu (2016) studied the compressive strength characteristics of concrete by partially replacing ordinary Portland cement with fly ash along with out at $0 \%, 15 \%$, $30 \%, 45 \%$ and $60 \%$ replacement of natural river sand. natural sand by crusher dust and waste marble powder in different proportions. It was found that $10 \%$ replacement of sand by crusher dust along with $20 \%$ replacement of ordinary Portland cement by fly ash gives satisfactory results. It was observed that the concrete containing fly ash, marble powder and crusher dust was more economical than normal concrete .M. Usha Rani et al (2016) studied the effect of crushed brick by using partially as fine aggregate in concrete. The sand was replaced by crushed bricks in steps of $15 \%, 20 \%$ and $25 \%$. It was observed that by using $20 \%$ of crushed brick the compressive strength increases whereas by using $25 \%$ of crushed brick the compressive strength decreases. The increment in compressive strength at the curing age of 7 - days was found to be $17.62 \%$ than of normal concrete and was obtained at $20 \%$ replacement, whereas at $25 \%$ replacement the decrement in compressive strength was found to be $1.277 \%$ than that of normal concrete. The splitting tensile strength and flexural strength were found best at $20 \%$ replacement. Chandrasekhar Reddy et al (2017) investigated the durability of concrete by replacing sand with quarry dust and cement with fly ash. The natural sand was replaced by quarry dust in steps of $0 \%, 10 \%, 20 \%$ and $30 \%$ and cement by fly ash in steps of

$0 \%, 10 \%, 20 \%$ and $30 \%$. The concrete containing fly ash was found to have low resistance to sulphuric acid solution over the control mix and most percentage loss in weight was observed at $20 \%$ replacement of quarry dust and fly ash. The maximum percentage loss of compressive strength was found at $20 \%$ replacement of quarry dust and $30 \%$ fly ash

\section{OBJECTIVE OF THE STUDY}

Clastic sediment Stone powder disposal has become a worldwide problem. Moreover over exploitation of natural construction materials has led to their depletion. The acute shortage of natural river sand has stimulated construction industry to go for an alternative material which can be used as replacement of natural sand. This study has been carried The following are the objectives of study

1. To compare the workability of M25 concrete by partial replacement of clastic sediment stone powder with fine aggregate in proportions of $0 \%, 15 \%, 30 \%, 45$

2. To study the effect of clastic sediment stone powder on compressive strength, splitting tensile strength and flexural strength for M25 concrete

\section{EXPERIMENTAL PROGRAMME}

Fine aggregate (natural river sand) was partially replaced by waste sand stone powder in the production of concrete in order to reduce the waste load and to obtain an alternative material of sand for production of concrete. Clastic Stone powder being a waste material when used as fine aggregate leads to economical production of concrete hence economical concrete construction and simultaneously compensates the shortage of natural river sand. Design concrete mix M25 of ratio 1:1.79:2.37 (IS: 10262 - 2009) was investigated adopting w/c ratio of 0.45 . For the production of concrete, material used were ordinary Portland cement 43 grade, natural river sand as fine aggregate, coarse aggregate, sand stone powder as replacement of natural river sand and potable water. The maximum size of crushed aggregate was $20 \mathrm{~mm}$

\section{BATCHING OF MATERIALS}

The measurement of materials for making concrete is known as batching.

Normally batching is done by two ways

I) Batching by volume

II) Batching by weight

Volume batching: is not ideal method of batching.

Weight Batching:This is the recommended method of batching Batching by weight is preferred over batching by volume.

\section{TESTS CONDUCTED ON FRESH CONCRETE}

Fresh concrete is defined as that concrete which can be moulded to any shape.The slump test is used for fresh concrete.

\section{WORKABILITY}

The workability of fresh concrete was determined by slump cone test. The test was done as per IS - 1199:1959

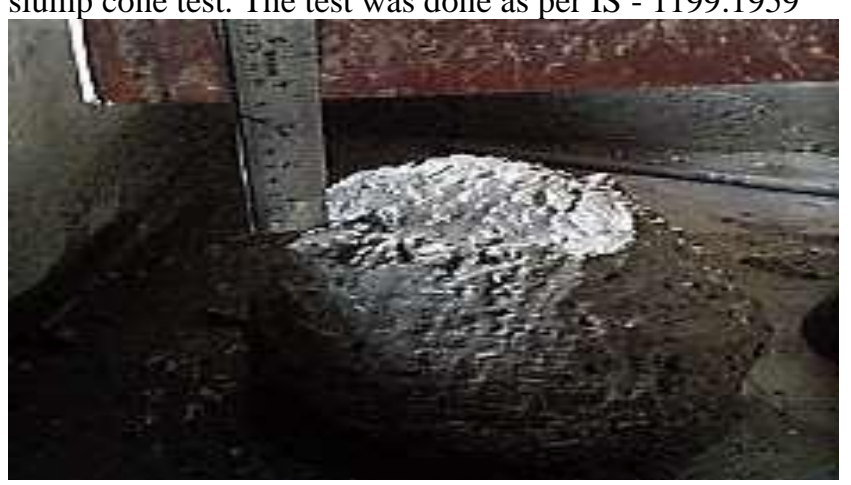

Fig. Determination of Slump value of concrete

\section{APPARATUS REQUIRED}

1. Mould in the form of a frustum of a cone having height $300 \mathrm{~mm}$, bottom diameter $200 \mathrm{~mm}$ and top diameter $100 \mathrm{~mm}$.

2. Tamping rod having diameter $16 \mathrm{~mm}$ and $60 \mathrm{~mm}$ long.

3. Non - porous base plate.

4. Measuring scale

\section{TEST PROCEDURE}

The internal surface of mould was cleaned. The mould was placed on non - porous base plate. The slump cone was with fresh concrete in four layers. Each layer was given 25 strokes by tamping rod. After filling the cone up to brim, the excess concrete was struck off by trowel. The cone was lifted gradually and horizontally and measurement was taken. Same procedure was done for all replacement levels. 


\section{TESTS CONDUCTED ON HARDENED CONCRETE}

$\begin{array}{ll}\text { I. } & \text { Compression test } \\ \text { II. } & \text { Splitting tensile test } \\ \text { III. } & \text { Flexural test }\end{array}$

COMPRESSION TEST (IS: 516 - 1959), Compressive strength test has been done as per IS: 516 1959. For determination of compressive strength, Concrete cubes having size $150 \mathrm{~mm} \times 150 \mathrm{~mm} \times 150 \mathrm{~mm}$ were casted, demoulded after 24 hours and cured for their respective test days. Six cubes were casted for each replacement level. The compressive strength has been checked at the age of 7 days and 28 days. The compression test has been done by compression testing machine (CTM). The total numbers of cubes casted were 60 .

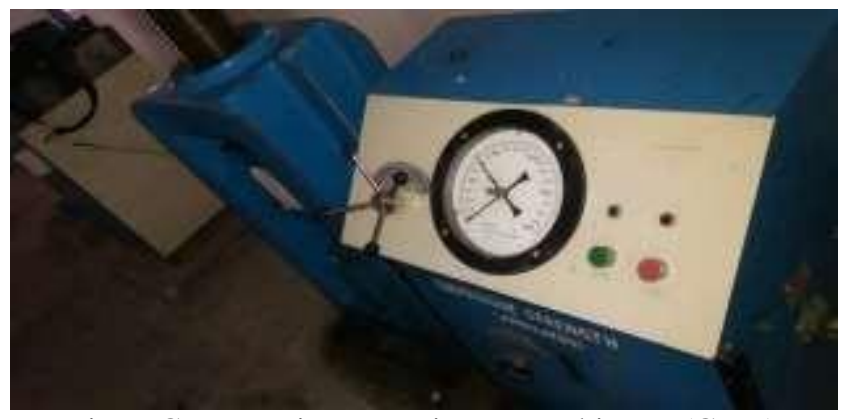

Fig. Compression testing machine (CTM)

\section{TEST PROCEDURE}

Cubes were taken out from curing tank; excess water was wiped off and left for dry. The bearing surface of compression machine was cleaned. The cubes have been placed in machine in such a manner that the load shall be applied to the opposite sides of cubes. The cubes were placed centrally on base plate and their top surface was touched with the movable part of the CTM. Load has been applied gradually and constantly at the rate of $140 \mathrm{~kg} / \mathrm{cm}^{2}$ /min. without any shock. The failure load was noted and the compressive strength was determined by formula given below

Compressive strength $(\mathrm{Mpa})=$ Failure load/ Cross sectional area

\section{SPLITTING TENSILE STRENGTH TEST (IS: 516 -} 1959)

For investigation of splitting tensile strength, concrete cylinders having size $150 \mathrm{~mm} \times 300 \mathrm{~mm}$ (diameter $\mathrm{x}$ height) were casted, demoulded after 24 hours and cured for 7 and 28 days. The splitting tensile strength has been checked at the age of 7 and 28 days. 3 cylindrical specimens were casted for each replacement. The splitting tensile strength test has been done by compression testing machine (CTM). Splitting tensile strength is calculated by formula, $\mathrm{f}_{\mathrm{t} .}=$ $2 \mathrm{P} / \pi \mathrm{DL}$

$\mathrm{P}=$ Failure load, $\mathrm{D}=$ diameter of cylinder, $\mathrm{L}=$ length of cylinder

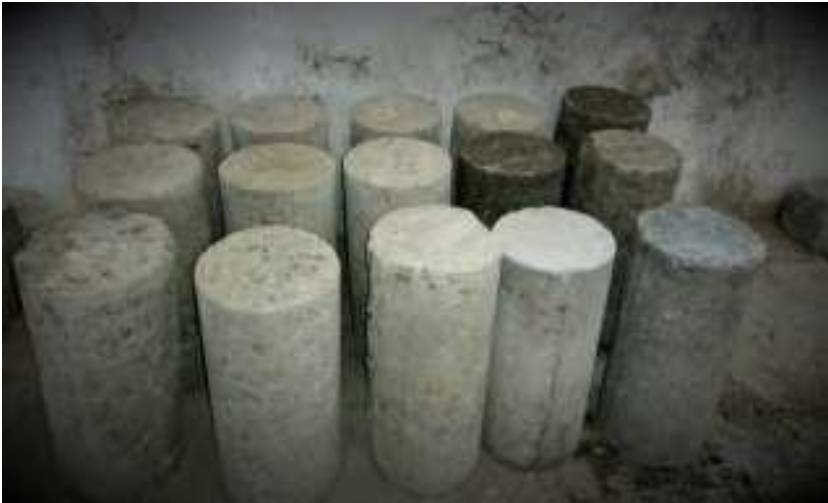

Fig. cylindrical concrete specimen

FLEXURAL STRENGTH TEST (IS: 516 - 1959)

For determination of flexural strength, concrete beams having size $700 \mathrm{~mm} \times 150 \mathrm{~mm} \times 150 \mathrm{~mm}$ were casted, demoulded after 24 hours and cured for 7 and 28 days. The flexural strength was checked at the age of 7 and 28 days. 3 beam specimens were casted for each replacement. Total numbers of 30 beam specimens were casted. The flexural test has been done by universal testing machine. According to IS code 516-1959, the specimen is tested under two point loadings over an effective span of $600 \mathrm{~mm}$ divided into three equal parts and restrained. The load shall be applied at the rate of $400 \mathrm{~kg} / \mathrm{min}$ for the $15.0 \mathrm{~cm}$ specimen and at a rate of $180 \mathrm{~kg} / \mathrm{min}$ for the $10 \mathrm{~cm}$ specimen.

Flexural strength is given by Flexural strength $(\mathrm{Mpa})=$ $\mathrm{PL} / \mathrm{bd}^{2}$

$\mathrm{P}=$ failure load, $\mathrm{L}=$ centre to centre distance between the support $(600 \mathrm{~mm}) \cdot \mathrm{b}=$ width of specimen, $d=$ depth

\section{RESULTS AND DISCUSSION}

The results of various experimental investigations carried out on raw materials, fresh concrete and hardened concrete and their graphical representation are presented in this chapter. The effect on the properties of concrete are also presented in this chapter.

\section{Properties of cement:}

In this study ordinary Portland cement (OPC) 43 grade conforming IS 8112: 1989 was used. The specific gravity of OPC is generally taken as 3.15 . The fineness of cement was 2.59 .

\section{Properties of fine aggregate:}

The aggregate fractions ranging from $4.75 \mathrm{~mm}$ to $150 \mu$ are termed as fine aggregates. The specific gravity of fine aggregate is 2.62, fineness of fine aggregate is 2.68 and water absorption is $1.21 \%$.

\section{Properties of coarse aggregate:}

The aggregate fractions ranging from $80 \mathrm{~mm}$ to $4.75 \mathrm{~mm}$ are termed as fine aggregates. The specific gravity of fine aggregate is 2.65, fineness of fine aggregate is 6.90 and water absorption is $0.81 \%$ 


\section{Properties of Clastic sediment stone powder}

Clastic stone powder is a fine material formed during the process of comminution of large size stones into coarse aggregate or crushed sand. The specific gravity of fine aggregate is 2.51 ,fineness of fine aggregate is 2.68 and water absorption is $1.83 \%$.

\section{WORKABILITY}

Workability of fresh concrete was determined by using slump cone and the results obtained are presented in Table .From experimental results it is evident that workability of concrete decreases as the percentage of stone powder increases

Table: Workability in terms of slump

\begin{tabular}{|c|c|c|c|c|}
\hline Replacement (\%) & $\begin{array}{c}\text { Sand } \\
(\%)\end{array}$ & $\begin{array}{c}\text { Stone } \\
\text { Powder } \\
(\%)\end{array}$ & $\begin{array}{c}\text { Slump } \\
(\mathrm{mm})\end{array}$ & $\begin{array}{c}\text { Reduction } \\
\text { in slump } \\
(\mathrm{mm})\end{array}$ \\
\hline 0 & 0 & 0 & 72 & - \\
\hline 15 & 85 & 15 & 58 & 14 \\
\hline 30 & 70 & 30 & 40 & 32 \\
\hline 45 & 55 & 45 & 28 & 44 \\
\hline 60 & 40 & 60 & 15 & 57 \\
\hline
\end{tabular}

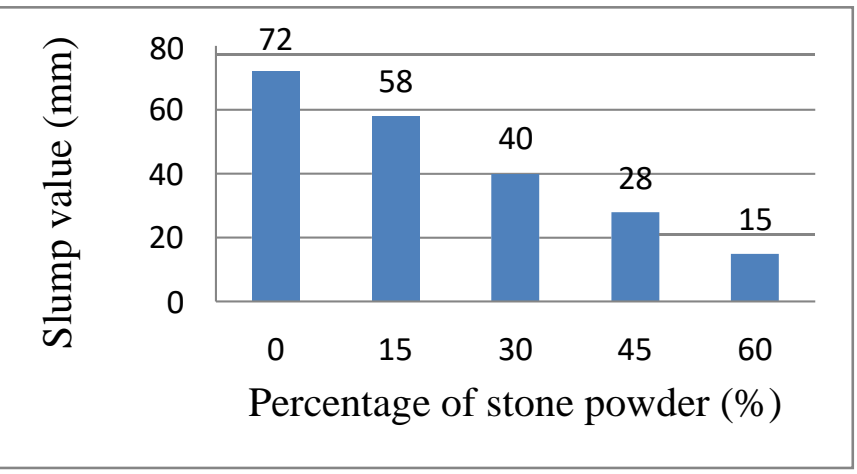

Fig. Slump values at different replacement levels

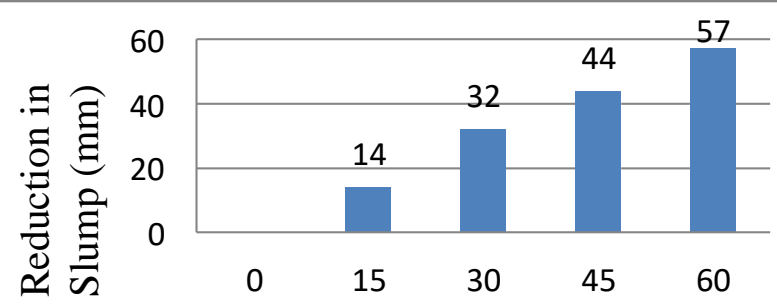

Percentage of stone powder $(\%)$

Fig. Reduction in slump COMPRESSION TEST

Compressive strength test has been done as per IS: 516 1959. For determination of compressive strength, Concrete cubes having size $150 \mathrm{~mm} \times 150 \mathrm{~mm} \times 150 \mathrm{~mm}$ were casted, demoulded after 24 hours and cured for their respective test days. Six cubes were casted for each replacement level. The compressive strength has been checked at the age of 7 days and 28 days

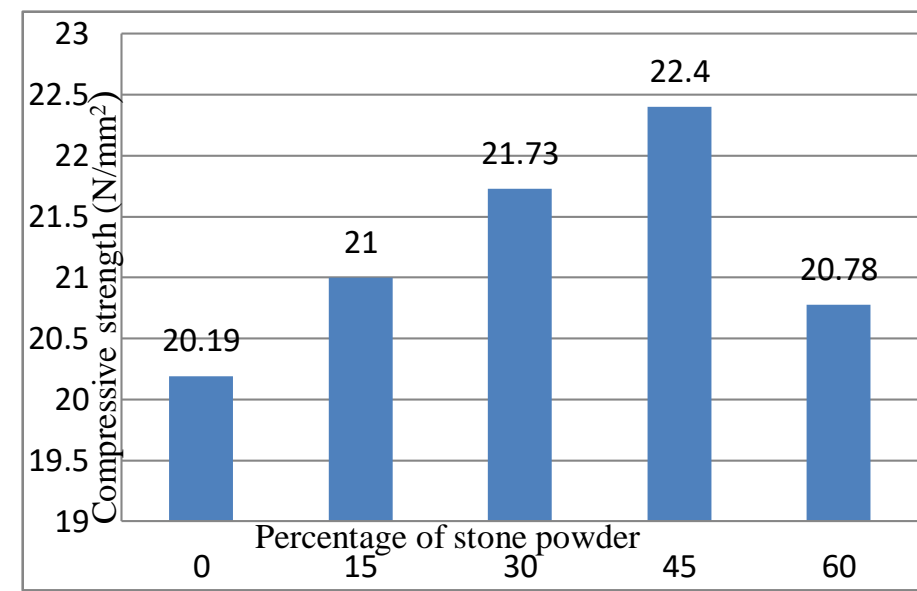

Compressive strength at 7 days

Compressive strength at 28 days
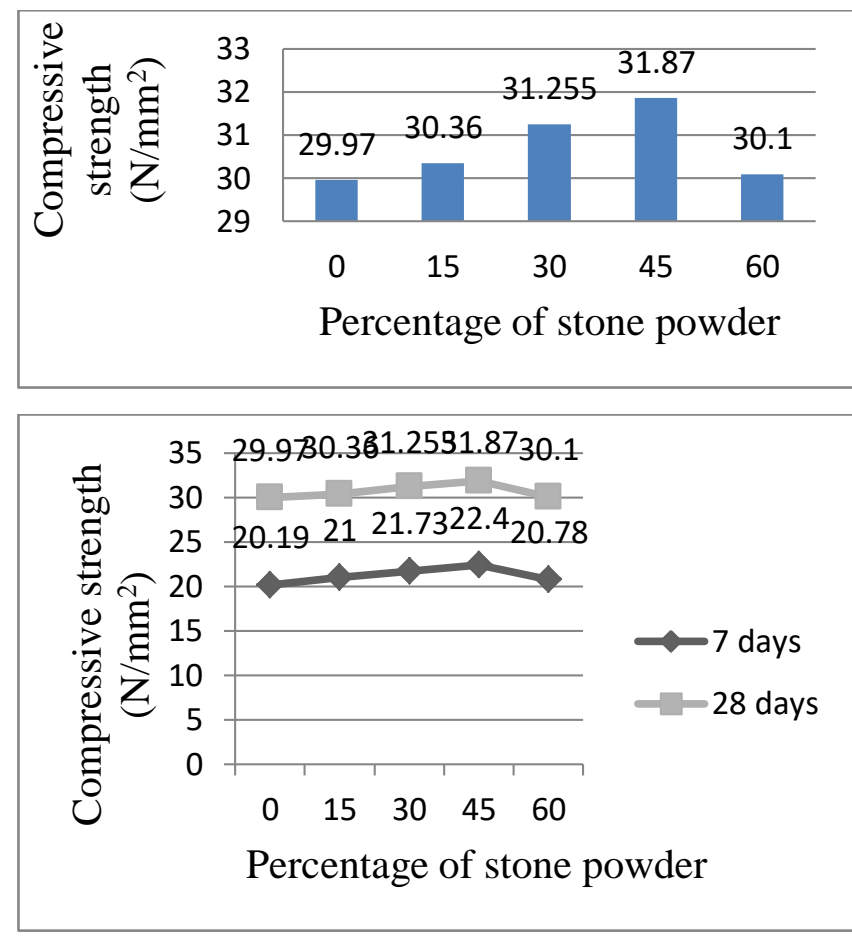

Comparison of compressive strength at 7 and 28 days

\section{SPLITTING TENSILE TEST}

The splitting tensile strength was determined at the curing age of 7 and 28 days. For each replacement 3 cylinders were casted and their average was taken as final splitting tensile strength. 

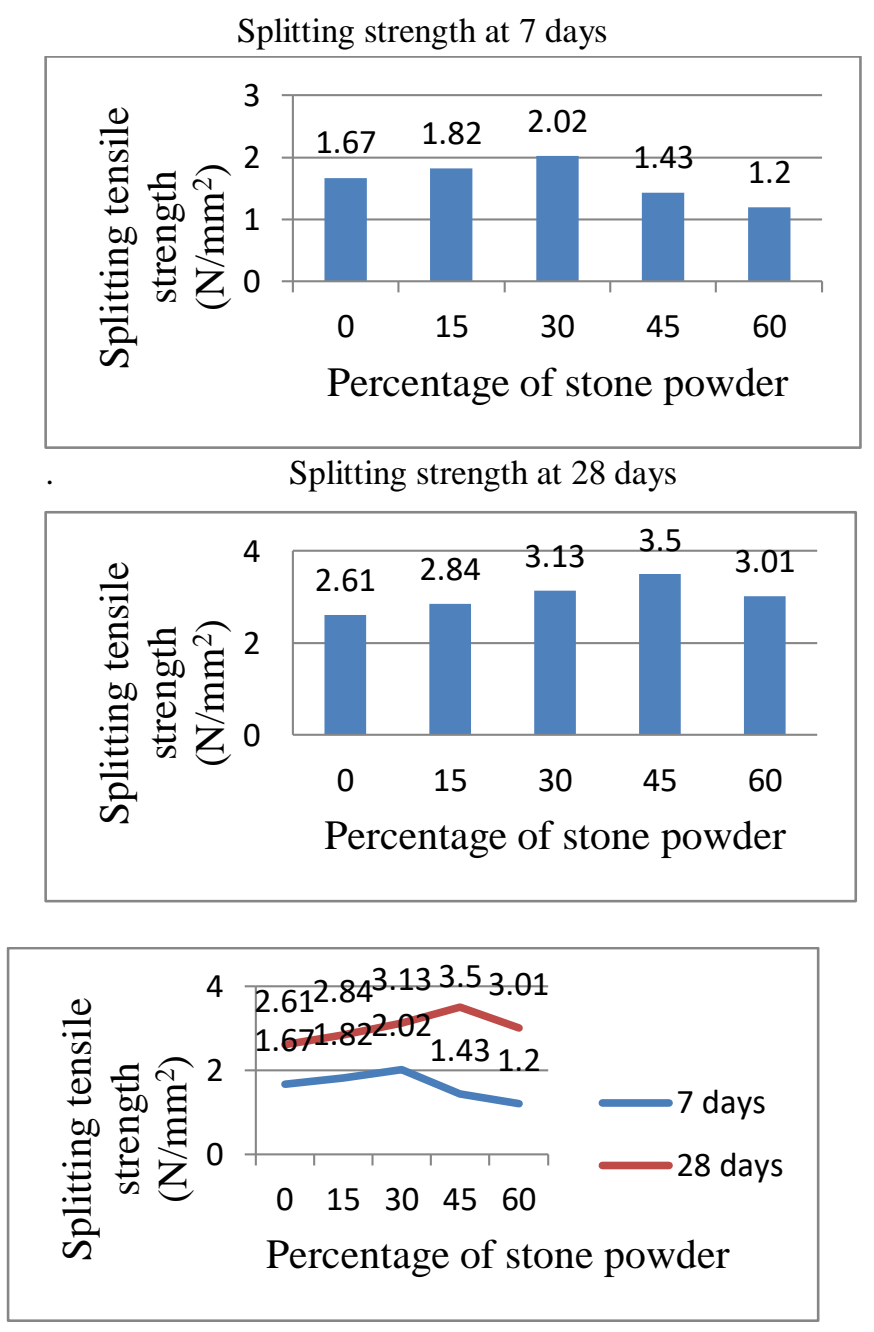

Comparison of splitting tensile strength 7 and 28 days

\section{FLEXURAL STRENGTH TEST}

The flexural strength was determined at the curing age of 28 days. For each replacement 3 concrete beams were casted and their average was taken as final flexural strength.

\section{Flexural strength at 7 days}

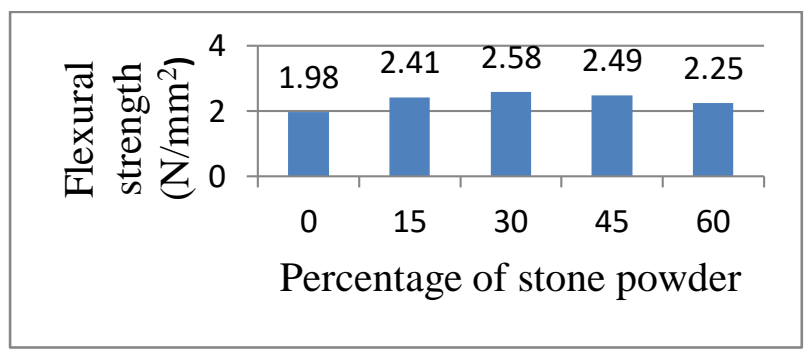

Flexural strength at 28 days
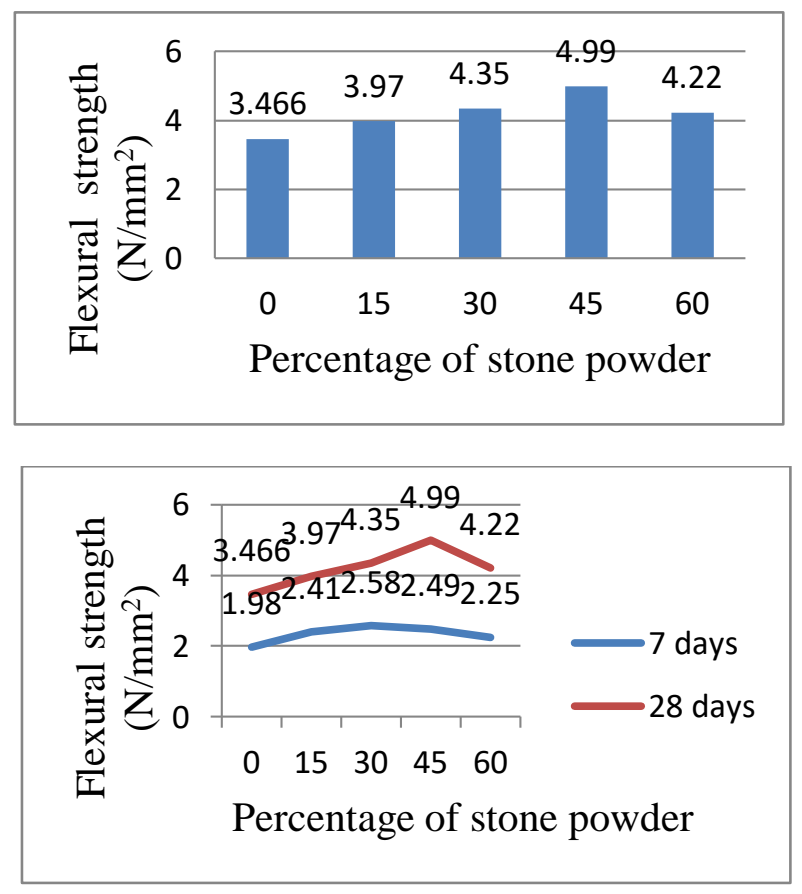

Comparison of flexural strength at 7 and 28 days

\section{CONCLUSIONS AND FUTURE SCOPE}

The following conclusions can be drawn from the present work.

1. The workability of concrete decreases with increase in stone powder content.

2. Compressive strength, splitting tensile strength and flexural strength increases by replacing fine aggregate with clastic stone powder.

3. After $45 \%$ replacement of fine aggregate with clastic stone powder when I compared the results, the difference between the $0 \%$ and $45 \%$ replacement of fine aggregate with stone powder, the compressive strength I got after 7 days of curing was $10.94 \%$ and that of after 28 days of curing it was $6.33 \%$.

4 .After $45 \%$ replacement of fine aggregate with clastic stone powder when I compared the results, the difference between the $0 \%$ and $45 \%$ replacement of fine aggregate with stone powder, the splitting tensile strength I got was $34 \%$ after 28 days of curing.

5. After $45 \%$ replacement of fine aggregate with clastic stone powder when I compared the results, the difference between the $0 \%$ and $45 \%$ replacement of fine aggregate with stone powder, flexural strength I got was $43 \%$ after 28 days of curing.

6. From this research it can be said that incorporation of clastic stone powder in concrete will definitely decrease the demand for natural sand and thereby help in sustainable development. Also, adoption of clastic stone powder as an alternative of sand in concrete will assist in protecting the environment. 


\section{FUTURE SCOPE}

1. Examine the acid resistance, porosity and durability of concrete by replacing fine aggregate with clastic stone powder fully.

2. Determine the mechanical properties of concrete construction units like hollow concrete blocks etc. by using clastic stone powder as fine aggregate.

3. Assess the effect of clastic stone powder on the mechanical properties of concrete at higher grades like M30, M35, and M40.

\section{REFERENCE}

[1] V. L. Bonavetti et al (1994) " The effect of stone dust content in sand" Cement and Concrete Research, Vol.24, no. 3, pp. $580-$ 590, 1994.

[2] Sudharshan N. Raman (2005) "Suitability of quarry dust as partial replacement material for sand in concrete" http:// www.researchgate.net/ publication/237806269.

[3] Sunilaa George (2008) et al " Replacement of river sand using manufactured sand and quarry dust in cement concrete" Nature Environment and Pollution Technology, Vol. 7, No. 3 pp. 475478 2008, Techno - Science Publications.

[4] Appukutty P. (2009) "Substitution of quarry dust to sand for mortar in brick masonry works" International Journal on Design \& Manufacturing Technologies, Vol. 3, No. 1, January 2009.

[5] Omar M. Omar (2012) "Influence of lime stone waste as partial replacement material for sand and marble in concrete properties" HBRC Journal, Vol. 8, Issue 3, December 2012, pp. 193-203.

[6] S. P. S. Rajput et al (2014) "Suitability of crushed stone dust as fine aggregate in mortars" International Journal of Emerging Technology and Advanced Engineering (Vol. 4, Issue 3, March 2014).

[7] Amit Kumar et al (2015) "Stone dust in concrete: effect on compressive strength" [International Journal of Engineering and Technical Research (IJETR) ISSN: 2321-0869 (O) 2454-4698 (P), Vol. 3, Issue-8, August 2015].

[8] Husam Najm (2016) " Experimental study of concrete made with granite and iron powders as partial replacement of cement" Sustainable Materials and Technologies, Vol. 9, September 2016 , pp. 1-9.

[9] Aditya Rana, et al (2016) "Recycling of dimensional stone waste in concrete a review" Journal of Cleaner Production, Vol. 135, 1 November 2016, pp. 312-331.

[10] Sarbjeet Singh et al (2016) "A review on properties of sustainable concrete using granite dust as replacement of river sand" Journal of Cleaner Production, Vol. 126, 10 July 2016, pp. 74-87.

[11] Prarthita Basu (2016) "Study compressive strength characteristics of concrete by partially replacing of ordinary Portland cement (OPC) with fly ash by using grade M35 along with partial replacement of natural sand by varying percentage of crusher dust and marble waste dust" International Research Journal of Engineering \& Technology (IRJET), Vol. 3, Issue 7 July 2016.

[12] Chandrasekhar Reddy et al (2017) "Investigation on durability properties of concrete with partial replacement of sand by quarry dust and cement by fly ash" International Journal of Research in Engineering and Applied Sciences (IJREAS) Vol. 7 Issue 6 , June-2017.

[13] Charles K. Kankam (2017) "Stress strain characteristics of concrete containing quarry rock dust as partial replacement of sand" Case Studies in Construction Materials, Vol. 7, December 2017, pp. 66-72

[14] IS: 8112 - 1989, Specifications for 43 grade ordinary Portland cement, Bureau of Indian standard, New Delhi.
[15] IS: 383 - 1970, Specification for coarse and fine aggregate from natural sources for concrete, Bureau of Indian standard, New Delhi.

[16] IS: 10262 - 2009, Guidelines for concrete mix design proportioning, Bureau of Indian standard, New Delhi.

[17] IS: 2386 (Part I - V) 1963, Methods of test for aggregates for concrete, Bureau of Indian standard, New Delhi.

[18] IS: 1199 - 1959, Methods for sampling and analysis of concrete, Bureau of Indian standard, New Delhi.

[19] IS: 516 - 1959, Methods of tests for strength of Concrete,Bureau of Indian standard, New Delhi 